Krzysztof Kijak

\section{NIEKTÓRE ASPEKTY POLITYKI GOSPODARCZEJ MALEZJI}

Wśród państw Azji Południowo-Wschodniej Malezja wyróżnia się nadzwyczaj wysokim tempem wzrostu gospodarczego. W ostatniej dekadzie wynosiło ono średnio $8 \%$ rocznie, czyli było kilkakrotnie wyższe niż w państwach wysoko uprzemysłowionych. Wynik taki zawdzięczała ona kilku czynnikom, jakie przedstawimy poniżej.

Jednym z powszechnie znanych i ważnych, choć nie najważniejszych, są bogate zasoby naturalne. Jeszcze przed uzyskaniem niepodległośc Malaje były największym eksporterem cyny. Również obecnie eksport tego metalu pokrywa $1 / 3$ światowego zapotrzebowania, chociaż w wyniku dekoniunktury wielkość wywozu spadła z 50-60 tys. t do 30-35 tys. $t$ w latach $90 .{ }^{1}$. W wyniku spadku cen zmniejszyła się również wielkość wpływów z jej eksportu. Ważnym wydarzeniem było odkrycie i rozpoczęcie eksploatacji bogatych złóż ropy naftowej oraz gazu ziemnego wzdłuż wybrzeża Półwyspu Malajskiego oraz w rejonie Sabah i Sarawak w Malezji Wschodniej (Borneo). Wydobywa się około 800 tys. baryłek ropy dziennie, a wartość eksportu — łącznie z płynnym gazem — wynosi około 5 mld USD rocznie.

Istotną rolę odgrywa rolnictwo, a w szczególności uprawy przemysłowe. Malezja jest największym światowym producentem oleju palmowego (ponad $8 \mathrm{mln}$ ton rocznie), a eksport tego produktu przynosi ponad $4 \mathrm{mld}$ USD. W produkcji kauczuku naturalnego Malezja zajmuje trzecie miejsce w świecie (produkcja roczna około mln ton, wpływy z eksportu około mld USD). Lasy Malezji dostarczają cennego i poszukiwanego na rynkach

Ponieważ zarówno wielkość produkcji jak eksportu ulega cyklicznym wahaniom, po dano w tym przypadku, jak i w odniesieniu do innych towarów masowych, przybliżone wartości średnioroczne. światowych drewna, którego eksport — około $10 \mathrm{mln}$ m sześciennych przynosi 2 mld USD rocznie. Innymi ważnymi uprawami są: trzcina cukrowa, ryż, sago, tapioka, kukurydza, orzechy kokosowe, orzeszki ziemne, warzywa i owoce (m. in. plantacje ananasów), a także tytoń, kawa, kakao i herbata.

Tak eksport bogactw naturalnych jak i produktów rolnych, odgrywajacy wciąż ważną rolę w gospodarce Malezji, uzależniały ją w znacznym stopniu od zmieniajacej sie cyklicznie koniunktury na rynkach światowych. Same nie zapewniłyby więc tak wysokiego tempa wzrostu gospodarczego, dzięki któremu Malezja znalazła się w gronie krajów nowo uprzemysłowionych drugiej generacji. Czynnikiem zasadniczym była konsekwentna polityka industrializacji, sformułowana w kolejnych, perspektywicznych i pięcioletnich planach społeczno-gospodarczych.

Warto zwrócić uwage, że polityka gospodarcza Malezji połaczyła zasady gospodarki wolnorynkowej $\mathrm{z}$ elementami interwencjonizmu państwowego. Ten ostatni przejawia się nie tyle w systemie nakazów i zakazów administracyjnych (chociaż tendencje takie występowały, zwłaszcza w pierwszych latach niepodległości), co w skutecznym stosowaniu instrumentów ekonomicznych, takich jak kurs waluty, stopa procentowa kredytów i lokat, przywileje i ulgi podatkowe dla inwestorów, itp.

Ważną role odgrywają także wyspecjalizowane agendy rządowe, odpowiedzialne za rozwój określonych gałęzi gospodarki. I tak, rozwój przemysłu nadzoruje i kontroluje Malezyjski Zarząd Rozwoju Przemysłowego (Malaysian Industrial Development Authority MIDA). Spełnia on również funkcję agencji do spraw inwestycji zagranicznych, dokonując oceny zgłaszanych projektów inwestycyjnych oraz wydając zgodę na ich realizację. Z kolei federalny Zarzad Zagospodarowania Ziem (Federal Land Development Authority - ,FELDA") zajmuje się karczowaniem lasów i pozyskiwaniem w ten sposób nowych terenów pod uprawy rolne. Malezyjska Korporacja Rozwoju Handlu Zagranicznego (Malaysia External Trade Development Corporation - „MATRADE") zajmuje sie promocja eksportu, wysyłaniem i przyjmowaniem misji handlowych, udziałem w międzynarodowych targach i wystawach oraz organizowaniem podobnych w kraju Agencja ta ma swoje biura w dwudziestu pięciu państwach w Europie, Azji, Afryce, Ameryce i Australii. Promocja turystyki, odgrywajacej coraz większa rolę w gospodarce, zajmuje się Malezyjski Urząd Promocji Turystyki (Malaysian Tourism Promotion Board - „MTPB"), posiadający również swoje biura w osiemnastu krajach. Istnieje wreszcie szereg dużych przedsiębiorstw państwowych, takich jak powstałe w roku 1974 „Petronas", mające wyłączność na poszukiwanie, wydobycie, przerób i dystrybucje ropy naftowej oraz gazu ziemnego, czy też utworzona w roku 1980 Malezyjska Korporacja Przemysłu Ciężkiego (Heavy Industries 
Corporation of Malaysia Bhd „HICOM"), zajmująca się rozwojem przemysłu maszynowego i produkcją stali. Przedsiębiorstwo to, we współpracy z japońskim koncernem Mitsubishi, uruchomiło w roku 1985 produkcję pierwszego malezyjskiego samochodu osobowego "Proton Saga". Samochód ten w jego kolejnych wersjach stał się nie tylko najbardziej popularnym pojazdem w Malezji, lecz jest również eksportowany do ponad dwudziestu krajów.

W okresie poprzedzającym proces szybkiego uprzemysłowienia, to jest do początku lat siedemdziesiątych, starano się ograniczyć import wyrobów przemysłowych, zastepujac go przywozem komponentów do finalnego montażu w kraju. Wobec niewielkiej chłonności rynku wewnętrznego, oszczędności z tego tytułu nie były jednak wielkie, a liczba nowoutworzonych miejsc pracy również nie odpowiadała potrzebom wynikającym z ówczesnego wysokiego bezrobocia. Zdecydowano sie wtedy na stworzenie nowych gałęzi przemysłu ukierunkowanych przede wszystkim na eksport. Był to jeden z kluczowych elementów tzw. Nowej Polityki Gospodarczej (New Economic Policy — „NEP"), sformułowanej w roku 1971, a obejmującej dwudziestolecie, do roku 1990, i konkretyzowanej w planach perspektywicznych oraz bardziej szczegółowych planach 5-letnich. Podstawowym celem Nowej Polityki Gospodarczej było zapewnienie harmonijnego rozwoju społeczno-gospodarczego kraju, stopniowa likwidacja sfery ubóstwa, zmniejszenie różnic w sytuacji materialnej poszczególnych warstw ludności i grup etnicznych, jak też poszczególnych regionów kraju.

Warto w tym miejscu przypomnieć, że jeszcze w roku 1970 blisko połowa ludności (dokładnie 49,3\% gospodarstw domowych) żyła w warunkach ubóstwa, dominującego w rejonach wiejskich. Podobnie duże różnice występowały w dochodach poszczególnych grup etnicznych. Najwyższe osiągała ludność pochodzenia chińskiego, a najniższe - Malajowie w większości zatrudnieni w rolnictwie. Różnice te doprowadzały w przeszłości do ostrych konfliktów etnicznych, z których najbardziej dramatyczny miał miejsce w roku 1969. Istniały wreszcie poważne różnice w stopniu rozwoju gospodarczego (a więc również dochodów) między poszczególnym rejonami kraju. Do najmniej rozwiniętych i najuboższych należały Sabah i Sarawak w Malezji Wschodniej. Stopniowa likwidacja ubóstwa miała nie tylko aspekt społeczno-polityczny lecz również ekonomiczny. Zdawano sobie sprawę, że wzrost realnych dochodów szerokich grup ludności zwiększy chłonność rynku wewnetrznego i będzie stanowił ważki impuls dla dalszego rozwoju i dywersyfikacji rodzimej produkcji.

Jak wspomniano powyżej, równolegle zakładano dynamiczny wzrost eksportu wyrobów przetworzonych i starano się w tym celu stworzyćc optymalne warunki dla inwestorów, zarówno miejscowych jak i zagranicznych. Początek lat siedemdziesiątych sprzyjał tym zamierzeniom, bowiem w tym właśnie czasie wiele firm z państw wysoko uprzemysłowionych dokonywało dyslokacji produkcji do rejonów o tańszej sile roboczej, a więc przede wszystkim do krajów rozwijających się. Malezja była $z$ wielu względów miejscem atrakcyjnym. Przede wszystkim dysponowała znacznymi zasobami stosunkowo taniej siły roboczej, a powszechna znajomość języka angielskiego ułatwiała proces szkolenia i kierowania zespołami ludzkimi. Miała lepiej rozbudowaną infrastrukturę (system bankowy, koleje, drogi, porty morskie i lotnicze, łączność) niż większość państw regionu. Wyróżniała ją również niska stopa inflacji oraz stabilność lokalnej waluty. Nie bez znaczenia była też dostępność na miejscu wielu surowców, wymienionych wyżej. Wreszcie stabilność polityczna a także stworzenie przez rząd wielu specjalnych ułatwień dla inwestorów (strefy wolnego handlu, ulgi i ,wakacje podatkowe") zachęcały firmy zagraniczne, w tym wielkie korporacje międzynarodowe, do lokowania w Malezji swoich zakładów produkcyjnych.

W początkowym okresie NEP nowe zakłady powstawały w różnych gałęziach przemysłu. Podobnie jak w wielu innych krajach regionu najszybciej rozwijał sie przemysł tekstylny. Wkrótce jednak dominujaca pozycję zajął przemysł elektrotechniczny i elektroniczny. Ich udział w eksporcie wyrobów przemysłowych wzrósł z $35 \% \mathrm{w}$ latach siedemdziesiątych do $65,7 \% \mathrm{w}$ roku, $1995^{2}$.

Lata osiemdziesiąte to okres wyraźnego preferowania przez państwo rozwoju określonych branż. Korzystając z doświadczeń Japonii, Korei Południowej i Tajwanu, jako główne branże rozwojowe określono przemysł elektroniczny oraz wybrane gałęzie przemysłu ciężkiego (produkcja stali i materiałów budowlanych, przemysł maszynowy i motoryzacyjny). Osiągnięte wskaźniki znacznie przekroczyły pierwsze założenia, o czym świadczą poniższe zestawienia ${ }^{3}$ :

Gałęzie przemysłu

Średnioroczne tempo wzrostu w \% (1986)

Osiągnięte wskaźniki

Elektrotechniczny

i elektroniczny

Środki transportu lądowego

(w tym samochody i części)

Maszyny i urządzenia

Żelazo i stal

Tekstylia i konfekcja
Założenia planu
(1992)

30,5

15,8

15,8

30,2

14,7

${ }^{2}$ Por. Kim Ong-Giyer, Malaysia's Drive into High Technology Industry", Institute of South-East Asian Studies, Singapore 1998. 
Zgodnie z przyjętymi założeniami w dekadzie 1981-1990 zamierzano utrzymać wysokie tempo wzrostu gospodarczego (średnio $8 \%$, w tym przemysł przetwórczy co najmniej $12 \%$ rocznie), oraz doprowadzić do pełnego zatrudnienia przez stworzenie blisko $2 \mathrm{mln}$ nowych miejsc pracy. Planowano zredukować strefę ubóstwa do $16,7 \%$ gospodarstw domowych Mimo niesprzyjających warunków na rynkach światowych na początku lat osiemdziesiątych (znaczny spadek cen cyny, kauczuku i drewna) zamierzenia te zostały w znacznym stopniu zrealizowane. Liczba gospodarstw domowych, zaliczanych do grupy biednych spadła o ponad 400 tysięcy (z 1,1 mln w roku 1970 do $619400 \mathrm{w}$ roku 1990, mimo wzrostu ogólnej ich liczby z 2,1 do 3,6 mln). Tym samym w strefie ubóstwa pozostało $17,1 \%$ gospodarstw ${ }^{4}$. Promowano również awans społeczny Malajów, tradycyjnie zamieszkujących głównie rejony wiejskie, podczas gdy w miastach dominowali Chińczycy. Zwiększyła się znacznie liczba tych pierwszych zarówno w przemyśle, jak i w innych zawodach. Ponadto tak Malajowie, jak pozostałe grupy etniczne, zwiększyły swój udział kapitałowy w gospodarce kraju, kosztem inwestorów zagranicznych.

Rok 1990 był końcowym etapem pierwszego planu perspektywicznego. Drugi plan perspektywiczny (The Second Outline Perspective Plan OPP2), obejmujący lata 1990-2000, zachowując główne elementy dotychczasowej polityki gospodarczej, miał stworzyć warunki, dzięki którym Malezja mogłaby stać się krajem wysokorozwiniętym w pierwszym dwudziestoleciu następnego wieku. Program ten, nazwany „Polityką rozwoju narodowego" (National Development Policy — NDP) przewidywał między innymi:

- zharmonizowany rozwój wszystkich gałęzi gospodarki narodowej;

- dalsze niwelowanie różnic między poszczególnymi regionami kraju, a także pomiędzy mieszkańcami miast i wsi;

- dynamiczny rozwój budownictwa mieszkaniowego;

- bardziej sprawiedliwy podział dochodów wśród grup ludności, w tym dalszą poprawę sytuacji materialnej „ludności rdzennej" (to jest Malajów);

- $\quad$ stałe podwyższanie kwalifikacji pracowników, zwiększenie nakładów na szkolnictwo wszystkich stopni oraz na prace naukowo - badawcze (,research and development");

- uwzględnienie w większym niż dotychczas stopniu spraw ochrony środowiska naturalnego.

${ }^{4}$ Patrz: Malaysia in Brief, Information Division. Ministry of Foreign Affairs, Kuala Lumpur [1998].
Plan zakładał również dalszy, dynamiczny wzrost dochodu narodowe go, postępujące uprzemysłowienie kraju, w którym w znacznie większym stopniu niż dotychczas miał partycypować sektor prywatny. Równolegle miał rozwijać się sektor publiczny, dla którego przewidziano w okresie pierwszego pięciolecia nakłady w łącznej wysokości 160 mld ringgitów, to jest według ówczesnego kursu około 64 mld USD. Kwoty te miały być przeznaczone przede wszystkim na dalszą rozbudowę infrastruktury, między innymi na budowe autostrad, modernizacje istniejacych oraz budowę nowych portów morskich i lotniczych, jak również budowę wielkiego centrum produkcji podzespołów i sprzętu informatycznego („,The Multimedia Super Corridor"). Duża wage przywiązywano do dalszego, szybkiego wzrostu eksportu i jego dywersyfikacji, zarówno asortymentowej jak geograficznej. Plan zakładał szczególnie dynamiczny wzrost wywozu przemysłu elektromaszynowego, co doprowadzić miało do poprawy salda bilansu handlowego i płatniczego. Rozwijane też miało być budownictwo mieszkaniowe, zarówno komunalne, dla grup ludności o niższych dochodach, jak i przez prywatnych deweloperów. Szczegółowy program w tym zakresie został opracowany przez kolejna, wyspecjalizowana agencję rządową - Zarząd Rozwoju Urbanistycznego (Urban Development Authority — „UDA").

Pierwsze lata realizacji planu wypadły pomyślnie. Średnioroczne tempo wzrostu produktu krajowego brutto za lata 1990-1996 wynosił 8,7\%. Szczególnie wysokie tempo wzrostu odnotował przemysł (11,2\% rocznie), w tym przemysł przetwórczy $(13,2 \%)$. Dynamicznie rozwijał się także sektor usług (średnioroczne tempo w omawianym okresie wyniosło 8,5\%), natomiast w produkcji rolniczej odnotowano umiarkowany wzrost rzędu $1,9 \%$. W rezultacie zmieniła się struktura produktu krajowego brutto, w którym dominującą pozycję zajmuje produkcja przemysłowa $(46 \%$, w tym przemysł przetwórczy $34 \%$ oraz usługi $41 \%)^{5}$.

W roku 1997 w wyniku pierwszych przejawów kryzysu finansowego, obejmującego większość krajów Azji Wschodniej i Południowo-Wschodniej, tempo wzrostu gospodarczego Malezji obniżyło się jedynie nieznacznie do 7,8\%. Nastąpił wprawdzie pewien spadek dochodu na głowę ludności (z 4,446 USD w roku 1996 do 4,136 USD w roku 1997), było to jednak głównie wynikiem deprecjacji miejscowej waluty. Produkcja przemysłowa, budownictwo oraz sektor usług wykazywały nadal wysoką dynamikę, osiągnięto też dobre wyniki w rolnictwie. W obrotach $\mathrm{z}$ zagranicą po dwóch latach ujemnego salda osiągnięto nadwyżkę w wysokości $424 \mathrm{mln}$

\footnotetext{
5 „Asia Yearbook 1977", Far Eastern Economic Review, Hong Kong.
} 
ringgitów, a stan rezerw dewizowych na koniec roku wyniósł 59 mld ringgitów

Dopiero w 1998 roku nasilający się w kryzys azjatycki doprowadził do większych perturbacji w gospodarce malezyjskiej, połączonej mocnymi więzami z gospodarką krajów regionu, a w szczególności z Japonią, Tajlandia, Indonezją i Singapurem. W rezultacie nastąpiło niewielkie zmniejszenie produktu krajowego brutto, a dalszej deprecjacji uległ ringgit (w pierwszych miesiącach roku 1998 jego kurs w stosunku do dolara amerykańskiego przekroczył 4). Wobec recesji na tradycyjnych rynkach zbytu oraz mniejszej chłonności rynku wewnętrznego zmniejszyła się wartość produkcji w większości gałęzi przemysłu, w tym elektromaszynowego, elektronicznego i motoryzacyjnego, jednocześnie gorsze wyniki zanotowano w rolnictwie. Nawet tradycyjny eksport drewna zmniejszył się w wyniku dekoniunktury na rynkach azjatyckich. Skutki kryzysu odczuło również budownictwo, z wyjątkiem mieszkaniowego, gdzie na ogół kontynuowano wcześniej rozpoczęte inwestycje. W wyniku wzrostu oprocentowania kredytu, wiele przedsiębiorstw, zarówno małych i średnich, jak i wielkich korporacji, znalazło się $w$ trudnej sytuacji finansowej. Odbiciem wszystkich tych zjawisk był znaczny spadek notowań na giełdzie w Kuala Lumpur.

W tych warunkach zadziwiajaco dobre wyniki osiagną handel zagraniczny. Nastąpił dalszy wzrost eksportu (do 78,7 mld USD) przy jednoczesnym spowolnieniu importu (76,1 mld USD), do czego przyczyniła się niewatpliwie znaczna dewaluacja ringgita. W rezultacie saldo bilansu handlowego było dodatnie i wyniosło ponad 2 mld USD.

Celem przeciwdziałania skutkom kryzysu rząd podjął szereg kroków naprawczych. Jeszcze pod koniec roku 1997 powołano zespół ekspertów, który pod nazwą Narodowej Rady Akcji Gospodarczej („National Economic Action Council" „NEAC") miał służyć jako konsultant rządu. Zespół ten opracował program naprawczy - Narodowy Plan Uzdrowienia Gospodarki (National Economic Recovery Plan - NERP), który w następujący sposób uszeregował główne kierunki działań:

- doprowadzenie do stabilizacji miejscowej waluty poprzez powiększenie rezerw dewizowych, wypracowania właściwej polityki kursowej oraz kontrole wysokości oprocentowania kredytów i lokat;

- ożywienie rynku wewnętrznego, m.in. poprzez udzielenie wsparcia finansowego przedsiębiorstwom szczególnie dotkniętym kryzysem;

- restrukturyzacja systemu bankowego, kontrola polityki kredytowej;

${ }^{6}$ Kurs ring gita wynosił: listopad $1996-1$ USD $=2,53$ ring; listopad $1997-1$ $\mathrm{USD}=3,29$ ring
- umocnienie podstaw gospodarki poprzez dalszą poprawę bilansu płatniczego, wzrost eksportu, utrzymanie równowagi budżetowej przy ograniczeniu wydatków na administrację;

- ochrona interesów ludności poprzez zahamowanie wzrostu bezrobocia, ograniczenie zatrudnienia obcokrajowców, stabilizację cen, przede wszystkim artykułów pierwszej potrzeby.

Określono również te dziedziny gospodarki, które szczególnie mocno odczuły skutki kryzysu i wymagają wsparcia. Na liście tej znalazło się 12 takich dziedzin, w tym większość gałęzi przemysłu, a także budownictwo, transport, ubezpieczenia i turystyka.

Program powyższy różnił się w znacznym stopniu od zaleceń MFW dla krajów dotkniętych kryzysem i został uzupełniony decyzjami o charakterze administracyjnym. Celem ukrócenia spekulacji wprowadzono zakaz handlu akcjami poza giełda w Kuala Lumpur oraz przejściowy zakaz wycofywania zagranicznych inwestycji kapitałowych. Kurs miejscowej waluty ustalono na poziomie 3,8 ringgitów za 1 USD. Obniżono oprocentowanie kredytów, stworzono również dodatkowe środki na finansowanie produkcji poprzez obniżenie wysokości rezerw obowiązujących banki.

Celem przezwyciężenia kryzysu rząd przeznaczył ponad 12 mld ringgitów (tj. wg aktualnego kursu prawie 3,2 mld USD) na rozbudowę infrastruktury oraz inne inwestycje stymulujące wzrost gospodarki, przy jednoczesnej rezygnacji z niektórych szczególnie kosztownych projektów.

Wbrew niektórym pesymistycznym prognozom podjęte środki nie wywołały paniki wśród inwestorów zagranicznych, przyjęte też zostały ze zrozumieniem przez większość przemysłowców miejscowych. Pierwsze miesiące 1999 roku wskazują, że podjęte środki są skuteczne i zjawiska kryzysowe zostaną $\mathrm{w}$ niedługim czasie przezwyciężone. W swoim niedawnym wystapieniu premier Malezji Mahatir przewidywał, że już w bieżącym roku gospodarka tego kraju wykaże niewielki wzrost, a w latach następnych powróci na drogę dynamicznego rozwoju.

\section{LITERA T URA}

Malaysia in Brief. Information Division, Ministry of Foreign Affairs, Malaysia, Kuala Lumpur [1998].

Asian Deuelopment Outlook 1996, 1997, Oxford University Press.

Asia and Pacific Review, The Economic and Business Report 1989, Saffron Walden, Essex (UK) 1990.

AnK) 10. Andrzej Żor, Male.

Asia Yearbook - 1997, 1998, 1999 - Far Eastern Economic Review Publishing Company, Hong Kong Far Eastern Economic Review - 1996, 1997, 1998. 